\title{
In Memory of Hans Ankum, a Scholar and a Friend
}

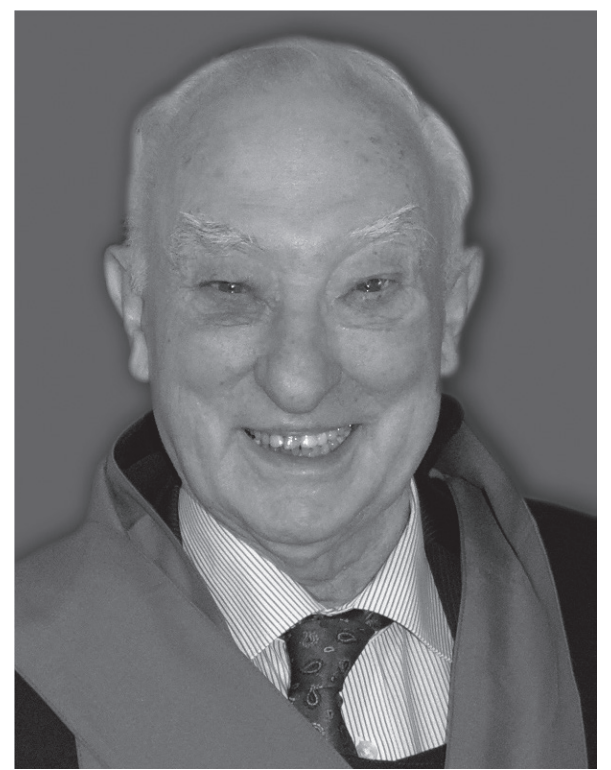

On the June 3, 2019, shortly before his 89th birthday, Prof. Dr. jur. Johan Albert Ankum passed away.
Hans Ankum, as his colleagues in the Romanist circles knew him, was not only a great scholar and professor, but also a mentor and a close friend to many of us - an important aspect since Amicitia as Hans used to say is an essential element of Romanist science.

Hans Ankum was born on July 23, 1930 into the family of (a social democratic) mayor of Koog aan de Zaan. Hans himself was a member of the left fraction of the Provincial council of North Holland. The beginnings of his career as a legal scholar and a Romanist were bright: they started in 1948-1953 when he attended the Faculty of Law of the University of Amsterdam. Later, between 1950-1953, Hans became specialized in juridical papyrology and medieval Roman law at the University of Leyden. Afterwards, the young scholar completed his advanced legal studies in Paris, Faculté de Droit between 1954-1956.

Between 1960-1963, Hans Ankum started to give lectures on Roman Law and Legal History at the University of Leyden. These had been the first steps in his long and remarkable career, which soon awarded him with a professorship. Before that, however, Hans was granted an LLD cum laude for his thesis on the actio Pauliana by the University of Amsterdam in 1962. Scientifically, the subject of his thesis was incredibly interesting. He was able to demonstrate the complex development of this ancient institute - from its Roman origins until its influence on later traditions. Therefore, the present-day reader remembers Hans not only for his profound and comprehensive knowledge about ancient Roman law but also for his expertise on the history of civil law and its modern trends. It was not by chance that Hans Ankum was already a Full Professor at the University of Leyden from 1963 to 1965, and then (1965-1995) 
a Full Professor at the University of Amsterdam specializing on Roman Law, Legal History, and Juristic Papyrology.

Upon examining the extensive list of his writings, we will detect immediately a deep understanding of ancient history and culture, but also Hans' talent to enter and reveal the details of the disputes between legal scholars. He found it especially interesting to tackle the technically difficult texts of Marcellus, Julian, Pomponius, Papinian, Paul, Ulpian, etc. In this area, professor Ankum followed the footsteps of his University of Amsterdam professor H. R. Hoeting by opposing the so-called "hunt for interpolation".

I still remember his seminars on the books of Papinian in the Digests according to Lenel's Palingenesia iuris civilis. The professor's vivid and profound discussion after the interpretation that involved all of the participants - Hans Ankum's primary students such as Eric Pool, Marjolijn van Gessel-de Roo, Laurens Winkel, Boudewijn Sirks, as well as visiting professors and other students. During these discussions, classical Roman legal scholars were considered as well as Cuiacius or modern scholars such as Kaser and Nörr, Pugliese, Talamanca, Corbino, Labruna, Theo Mayer Maly, Herbert Hausmaninger and many others. Thus, I entered the realm of juridical exegesis, looking for strict legal questions, answers, and arguments. Sometimes at the end of the sessions, Hans liked to remind us that atop of the imaginary legal scholar pyramid sat Papinian, then somewhat below him Lenel, and much lower sat our guild - the modern scholars. Since the professor always liked to remind us that reading the Digests allowed him to discover something new every day, reading the ancient jurisprudence became very intriguing to me. For such texts, the key was to correctly understand the fundamental principles of the texts and the exegesis made in the proper environment. This was the vehicle for truthful conclusions that could bring some novelty to the scientific society. Using such a method, Hans Ankum was prepared to have long lasting disputes with his colleagues like the famous one with Max Kaser about furtum pignoris and furtum fiduciae that lasted twenty years.

Scientific and professional organisations recognised his esteemed merits in the Netherlands and abroad. In 1986, Hans Ankum was elected an Ordinary Lifetime Member of the Royal Dutch Academy of Arts and Sciences. He held several titles of doctor honoris causa: Aix-Marseille; Free University Brussels; University Ruhr, Bochum; University of Belgrade; Charles University, Prague; University of Murcia; and University of National and World Economy, Sofia. In 2012, he was conferred with Premio Ursicino Alvares (by Fundación Seminario de Derecho Romano Ursicino Álvarez).

Many of the Romanists from second half of the 20th and 21st centuries were not only his colleagues but friends as well. This was for instance clear from the volumes dedicated to honour his 65th birthday, edited by professors Feenstra, Spruit, Sijpestein, and Winkel. The volumes featured authors such as Ameloti, Archi, Churruca, Corbino, Honoré, Humbert, Levy, Krampe, Knutel, Metro, Miquel, Nörr, Wacke, Wubbe, etc. (this is only a short list of the collection of authors and is not meant to underestimate any of the authors not mentioned here).

His articles were often featured in the most important scientific reviews like Zeitschrift der Savigny-Stiftung für Rechtsgeschichte, Romanistische Abteilung, Tijdschrift voor Rechtsgeschiedenis, Revue internationale des Droits de l'Antiquité, Labeo, Iura, Index, but also in many other editions dedicated for instance to different scholars, etc. In a collection of his works, edited in 2014 (Spain, for the Uricino Alvares Premium), the review 
mentions 327 texts until 2013 - a number he extended by continuing to publish in the years following.

His works on utilitas, responsibility for eviction, the differences of actio de auctoritate and actio empti, favor libertatis, foenus nauticum, the aforementioned furtum pignoris and furtum fiduciae are some of subjects attracting high interest in the scientific community. Hans Ankum's analyses of the style of Papinian for instance show his acute sense of understanding of the deep dogmatic issues of juridical reasoning from case to case, which he demonstrated by distinguishing opinions of different ancient legal scholars, and many times by decoding their abstract and synthesised wording. These issues were, therefore, the core of Romanist exploration for him without underestimating the historical and social backgrounds of juristic mind. The interests of our late professor also covered the development of modern Civil law and especially the importance of the Dutch Civil Code. On this topic I adhere to the conclusions of Johannes Emil Spruit, who called him giurista purosangue in an earlier collection of Hans Ankum's operas (Extravantes, Naples, 2007, a cura di Carla Masi Doria and Spruit), describing the focus of his studies within Western European and Dutch Law. These studies were based on Roman law and were his primary interest. The researcher could not miss his fundamental studies of eviction, real securities, dotal rights, minors, fiducia - unknown to the Dutch Civil Code, but recognised by Court of Cassation in 1928, repealed in 1992 and restored again by the Court of Cassation in 1995. To this list, we can add studies on acceptilatio, lex Aquilia, Salvius Iulianus /D. 9,2,51 pr/, adulterium, dotis dictio, favor libertatis, tabeliones, the term of ambultorius, infanti proximi, Lex Laetoria, edictum de his qui deiecerit vel effunderint, manumissio fideicommissaria etc. This abundance of subjects and analyses is impressive not only due to the richness of ideas about dogmatic and social details, but also because of correct juridical questions, reconstructions of the factual situation of the ancient legal scholar, and Hans Ankum's intuition for precise legal argumentation.

It is necessary to stress that he did not study or work as a solitary scholar. Just like the Roman legal scholars, he understood juridical investigation as a dialogue among scholars which is the correct approach to proving the conclusions made. Such cooperation motivated him to support and encourage many seminars, conventions, and scholarly societies, i.a. SIHDA, French SHD, or the seminars of Copanello and Soverato, organised by Alessandro Corbino and Antonino Metro. For decades, he was the main co-ordinator of SIHDA and the vice president of SHD. Hans Ankum believed that not only the scholarly elite should participate in scientific discussions, but that these should also include young or completely new researchers. He did not only state the need to include them but continued to promote this trend. Therefore, he had many friends all around the world not only among the developed scholars, but what is even more important among the younger generation. It was usual to see him spending hours in discussion with young colleagues or going through hundreds of pages for an Eastern European scholar. He also made it possible for these persons to participate in and to speak in front of the larger scientific public.

Hans spoke many languages - primarily French and German, as well as Italian, English and Spanish, but never imposing his preferences onto others. I still remember very well my first stay in Amsterdam, when all the participants of his Papinian seminar spoke in English because of me. Hans introduced me by saying "this is our friend from Bulgaria and let us speak English from now on". In these beautiful months, I only spoke English. I even 
presented some texts from my studies in front of the seminar. Sometime later, he confessed that at the start of the seminars, the other participants did not understand much of my English or my Roman law. A year later towards the end of another Amsterdam visit, Hans asked me if I wanted to join a seminar in Italy. It felt like a dream come true. However, he told me that he had already told professor Corbino that I could speak Italian. In reality, at that point I was only able to understand articles in the beautiful Italian language thanks to Latin classes at the Classical college I had attended in Sofia. It was the end of July and upon my return to Sofia, I took intense classes in Italian. In September, I started my first colloquial experience in the language of Dante. The intervention in Soverato was a rare example of a person speaking English, but I also tried to speak Italian with the colleagues. Thanks Hans Ankum I not only learned to make legal exegesis, significantly improved my Roman law knowledge but also expanded my English and Italian skills. I continued expanding these skills in the years to come. Hans always tried to help us by insisting on the the clarity of presentation, correct translation, and exegesis of the sources, and by instructing us to strive to find new elements in the studied sources.

He aimed his own scientific research at difficult issues of Roman law. His research was always remarkable for its clarity, his language skills were perfect examples of eloquence. He also possessed the skill of understanding the interests of his audience and was able to deliberately discuss many specific topics.

His dedication to working with young scholars in the Netherlands was well known and an essential element of his portrait. Some of the scholars he supported were e.g. Eric Pool, professor in Amsterdam and Brussels, Laurens Winkel, professor in Rotterdam, Boudewijn Sirks, professor in Frankfurt and Regius professor of Civil law of Oxford, Gijsbert Noordraven - the first winner of Premium Boulvert in 1988, but also scholars from Spain, Central and Eastern Europe such as Hungary, Czech Republic, Russia, or South Africa, Chile etc. (some of his students, followers, and friends were Milena Poloyac, Michal and Petra Skrejpek, Zika Bujuklic, Dmitry Dozhdev, Leonid Kofanov, Patricio Carvajal, myself etc.).

Through his friendships, Hans Ankum also supported many initiatives in different countries such as the forum romanum in Belgrade, the permanent seminar Diritto romano e attualità, in which he personally participated alongside Eric Pool during the seminar's first meeting in Sofia, the review Ius Antiquum, etc. There have been conferences and studies in his honour, edited in Prague and Moscow, a cura of the professors Kofanov, Sacchi, Skřejpek and Tanev, and their assistants.

His support was crucial for the advancement of Roman law in Bulgaria, where he kept scientific contacts with four generations of scholars starting with professors Andreev and Milkova, later Cholov and Piperkov, and with our generation as well.

He cooperated with his Bulgarian colleagues many times by giving lectures, providing literature, or hospitality, but most of all by developing friendships with them. I still remember his lecture about eviction in Sofia when I was in the second year at the Law Faculty of the Sofia University. His advice given during the lengthy discussions about fragments remained for foenus nauticum. He personally pledged his efforts to founding our centre of Roman law in UNWE, giving lectures, promoting our research, and standing with us on several occasions.

In 1970, Hans Ankum married Pelline Van Es. They have one daughter together, named Anne-Barbara. At their home, they often welcomed colleagues and friends from Romanist 
circles and shared their time with many friends, giving us their warmest welcome, love and friendship.

Besides his scientific interests and university engagements, Hans Ankum had a passion for classical music. He himself was known to play the piano, collect CDs with performances from all over the world, and to regularly attend performances of Concert Gebouw orchestra. He did not only remember the names of operas or composers but also of conductors or musicians based on their style or tempo.

Until the last days of his life, Hans Ankum retained his analytical thinking and his love for his field and colleagues. He will always remain a remarkable and important friend and mentor for many of his friends and colleagues.

Konstantin Tanev

doi: 10.14712/2464689X.2020.22 